\author{
KAZIMIERZ ORTYŃSKI \\ JACEK WOŁOSZYN \\ https://doi.org/10.33995/wu2021.4.5
}

\title{
Efektywność techniczna zakładów ubezpieczeń w dziale ubezpieczeń non-life
}

Rynek ubezpieczeń jest istotnq częściq systemu finansowego, a działalność ubezpieczeniowa jest ważnym elementem w zarzqdzaniu ryzykiem i zarzqdzaniu zmiennościq dochodów. Celem autorów było zbadanie efektywności kosztowej oraz efektywności zysków ubezpieczycieli oraz ich relacji, z wykorzystaniem metody stochastycznej analizy granicznej (SFA). W opracowaniu wykorzystano metody statystyki opisowej oraz model SFA. Modele SFA należa do parametrycznych stochastycznych modeli granicznych, służacych do oszacowania nieefektywności. Efektywności badanych ubezpieczycieli oszacowano na podstawie wyznaczonych wartości nieefektywności. Przedmiotem analizy były dane roczne 18 firm ubezpieczeniowych (spółek akcyjnych) w dziale ubezpieczeń non-life, w Polsce w latach 2011-2019. W badaniu wykazano, że przeciętna efektywność kosztów wyniosła 0,6958, a przeciętna efektywność zysków 0,8382. W badanym okresie wystapiła relatywnie wyższa zmienność w efektywności kosztów niż w efektywności zysków oraz niska korelacja między wartościami tych efektywności. Dokonano też oceny struktury i rozwoju sektora ubezpieczeń non-life w Polsce z uwzględnieniem wybranych krajów UE.

Słowa kluczowe: rynek ubezpieczeń non-life, efektywność kosztów, efektywność zysków, stochastyczna analiza graniczna.

Klasyfikacja JEL-C52, D24, G22, L11

\section{Wprowadzenie}

Problematyka efektywności przedsiębiorstw i metod pomiaru efektywności jest szeroko rozwijana w literaturze ekonomicznej. 
Efektywność przedsiębiorstwa określa się, biorąc pod uwagę sposób transformacji czynników produkcji (nakładów) w efekty. Sposób tej transformacji (technologia produkcji) zależy od wyboru przez przedsiębiorstwo określonej kombinacji nakładów i efektów.

Natomiast nieefektywność przedsiębiorstwa może wynikać bądź ze zbyt dużych w stosunku do wymagań technologicznych nakładów czynników produkcji dla uzyskania danej wielkości produkcji, bądź nieadekwatności proporcji nakładów czynników produkcji do cen rynkowych czynników produkcji. Nieefektywność przedsiębiorstwa wystapi na przykład, jeśli jego produkcja jest niższa od produkcji potencjalnej, tj. możliwej do osiagnnięcia przy danych nakładach czynników produkcji ${ }^{1}$.

Prace nad efektywnością przedsiębiorstwa z wykorzystaniem podejścia granicznego zapoczątkował M. Farell²,wyróżniając m.in. efektywność techniczną, która oznacza zdolność przedsiębiorstwa do wytworzenia maksymalnej produkcji z danego zestawu czynników produkcji, albo wytworzenia określonej ilości produkcji przy minimalnych nakładach czynników produkcji . Kontynuowanie badań nad efektywnością techniczną doprowadziło w końcu lat 70. XX wieku do ukształtowania się dwóch głównych nurtów pomiaru efektywności technicznej, tj. parametrycznych stochastycznych modeli granicznych ( $\mathrm{np}$. Stochastic Frontier Models-SFM względnie SFA-Stochastic Frontier Approach) ${ }^{3}$ oraz nieparametrycznej deterministycznej metody obwiedni danych (Data Envelopment Analysis-DEA) ${ }^{4}$.

Metoda parametryczna oparta jest na wykorzystaniu modeli ekonometrycznych funkcji ekonomicznej, np. funkcji produkcji, funkcji kosztów czy funkcji zysków, oraz na oszacowaniu nieefektywności ze składnika resztowego modelu. W metodzie SFA niezbędne jest przyjęcie a priori założeń co do postaci funkcji określającej zależności między nakładami a efektami oraz rozkładu składnika losowego ${ }^{5}$. Metoda ta pozwala na określenie granicy efektywności oraz na wyodrębnienie w odchyleniach od krzywej efektywności czynników przypadkowych oraz błędów pomiaru (szumów statystycznych) i nieefektywności.

Natomiast metody nieparametryczne nie uwzględniaja występowanie składnika losowego oraz wykorzystuja metody programowania liniowego.

Badanie efektywności sektora finansowego, w tym zakładów ubezpieczeń, ma duże znaczenie zarówno z punktu widzenia mikro- jak i makroekonomicznego. Wzrost efektywności wpływa na wzmocnienie konkurencyjności, poprawę wizerunku instytucji ubezpieczeniowych, a także ocenę regulatorów czy organów nadzorczych ${ }^{6}$. Z makroekonomicznego punktu widzenia efektywność sektora ubezpieczeń wpływa na koszt ubezpieczeń i stabilność rynków ubezpieczeniowych.

1. J. Marzec,A. Pisulewski,A. Prędki, Efektywność techniczna i produktywność polskich gospodarstw rolnych specjalizujacych się w uprawach rolnych, „Gospodarka Narodowa” 2019, nr 2 (298), s. 96 i nast. oraz J. Marzec, A. Pisulewski, Pomiar efektywności zróżnicowanych technologicznie gospodarstw rolnych w Unii Europejskiej, ,Gospodarka Narodowa” 2020, nr 3(303), s. 111-114.

2. M. Farrell, The Measurement of Productive Efficiency, "Journal of the Royal Statistical Society" 1957,Seria A, Vol. 120, No. 3, s. 255-260.

3. Por. D. Aigner, C. Lovell, P. Schmidt, Formulation and estimation of stochastic frontier production function models, "Journal of Econometrics"19?7, No. 6, s. 21-37 oraz W. Meeusen, J. van den Broeck, Efficiency estimation from Cobb-Douglas production functions with composed error, "International Economic Review"1977, No. 18[2], s.435-444.

4. Por. A. Charnes, W.W. Cooper, E. Rhodes, Measuring the Efficiency of Decision Making Units, "European Journal of Operational Research"1978, Vol. 2, s.429-444.

5. Jak się podkreśla, głównym mankamentem metody SFA jest niezbędność określenia założeń a priori co do rodzaju rozkładu składnika nieefektywności, por. np. D. Holló, M. Nagy, Bank Efficiency in the Enlarged European Union, Budapest, "MNB Working Papers" 2006, No. 3, s. ?, http://pdc.ceu.hu/archive/00004387/01/wp2006_3.pdf [dostęp:6.08.2021].

6. M.D. Delis, A. Koutsomanoli-Fillipaki, Ch. K. Staikouras, Evaluating cost and profit efficiency: A comparison of parametric and non-parametric methodologies, "MPRA Paper" 2009, No. 14039, s. 2-3, https://mpra. ub.uni-muenchen.de/14039/ [dostęp: 6.08.2021]. 
Wskazuje się, że jednym z głównych celów podmiotów sektora finansowego (firmy ubezpieczeniowej] jest efektywność zysków, natomiast efektywność kosztów może być ważnym sposobem osiągnięcia efektywności zysków w dłuższym horyzoncie czasowym?

Przedmiotem badania relacjonowanego w artykule była efektywność kosztów (cost efficiency) i efektywność zysków (profit efficiency) zakładów ubezpieczeń, oparta na mikroekonomicznej teorii produkcji.

Badając efektywność kosztów, przyjmuje się, że ubezpieczyciel minimalizuje koszty, dokonując wyboru odpowiedniej kombinacji swoich nakładów i produktów (efektu) w zależności tylko od cen nakładu i produktu (input oriented approach) ${ }^{8}$.

W opracowaniu wykorzystano metody statystyki opisowej oraz model SFA, służący do oszacowania nieefektywności. Efektywności badanych ubezpieczycieli oszacowano na podstawie wyznaczonych wartości nieefektywności.

Głównym celem przyświecającym autorom było zbadanie efektywności kosztów oraz efektywności zysków ubezpieczycieli oraz ich relacji, poprzez zastosowanie metody SFA. Wykorzystano do tego dane 18 wybranych zakładów ubezpieczeń w dziale ubezpieczeń non-life w Polsce z lat 2011-2019. Podjęto też próbę oceny struktury i rozwoju sektora ubezpieczeń non-life w Polsce z uwzględnieniem wybranych krajów UE.

\section{Kluczowe cechy sektora ubezpieczeń non-life w Polsce}

Polski rynek ubezpieczeń po 2004 roku stał się częścią jednolitego europejskiego rynku ubezpieczeń. Zasady funkcjonowania rynku ubezpieczeń oparte są na regulacjach związanych z ich harmonizacja, kształtowaną zarówno przez europejskie prawo wspólnotowe, jak i prawo polskie (kodeksy, ustawy ubezpieczeniowe oraz inne ustawy, a także akty prawne wykonawcze do ustaw).

Rynek ubezpieczeń non-life w Polsce na tle rynków ubezpieczeń w krajach UE należy do rynków na stosunkowo niewysokim poziomie rozwoju.

Tabela 1. Składka przypisana brutto w dziale ubezpieczeń non-life w wybranych krajach UE w latach 2011, 2014, 2017, i w 2019 roku (w mln USD)

\begin{tabular}{|l|c|c|c|c|}
\hline & 2011 & 2014 & 2017 & 2019 \\
\hline Niemcy & 178083 & 192580 & 198013 & 203040 \\
\hline Francja & 104344 & 105399 & 140713 & 147082 \\
\hline Hiszpania & 45766 & 42992 & 40979 & 43325 \\
\hline Polska & 8540 & 8325 & 9996 & 11255 \\
\hline Czechy & 4695 & 4179 & 3951 & 4901 \\
\hline Węgry & 1842 & 1619 & 1804 & 2204 \\
\hline
\end{tabular}

Źródło: OECD data, https://stats.oecd.org/ [dostęp: 11.10.2021].

7. A.N. Berger, L.J. Mester, Inside the black box: What explains differences in the efficiencies of financial institutions, "Journal of Banking and Finance" 1997, No. 21, s. 895-947.

8. J. D. Cummins, M. A. Weiss, Analyzing Firm Performance in the Insurance Industry using Frontier Efficiency and Productivity Methods, s. 2-6, https://www.researchgate.net/publication/225904162_Analyzing_Firm_Performance in the_Insurance_Industry_Using_Frontier_Efficiency_and_Productivity_Methods/download [dostęp: 6.08.2021]. 
Składka przypisana brutto w dziale ubezpieczeń non-life była istotnie niższa w Polsce niż w wyróżnionych zachodnich krajach UE. Różnica w rozwoju tych ubezpieczeń jest szczególnie widoczna w porównaniu do takich krajów UE, które mają nieznacznie większą liczbę ludności, np. jak Hiszpania.

Tabela 2. Wskaźniki penetracji i gęstości w dziale ubezpieczeń non-life w wybranych krajach UE w 2011, 2014, 2017 i 2019 roku

\begin{tabular}{|l|c|c|c|c|c|c|c|c|}
\hline \multirow{2}{*}{ Kraje UE } & \multicolumn{2}{|c|}{2011} & \multicolumn{2}{c|}{2014} & \multicolumn{2}{c|}{2017} & \multicolumn{2}{c|}{2019} \\
\cline { 2 - 10 } & $\mathrm{p}$ (w \%) & $\mathbf{g}$ (w USD) & $\mathrm{p}$ (w \%) & $\mathrm{g}$ (w USD) & $\mathrm{p}$ (w \%) & $\mathrm{g}$ (w USD) & $\mathrm{p}$ (w \%) & $\mathrm{g}$ (w USD) \\
\hline Niemcy & $\mathrm{bd}$ & $\mathrm{bd}$ & 3,5 & 1674 & 3,7 & 1641 & 3,7 & 1743 \\
\hline Francja & 3,1 & 1424 & 3,2 & 1427 & 4,5 & 1798 & 4,5 & 1885 \\
\hline Hiszpania & 2,8 & 879 & 2,7 & 809 & 2,7 & 765 & 2,7 & 812 \\
\hline Polska & 1,6 & 220 & 1,5 & 214 & 1,8 & 249 & 1,8 & 277 \\
\hline Czechy & 2,0 & 434 & 1,9 & 386 & 1,7 & 360 & 1,9 & 448 \\
\hline Węgry & 0,5 & 182 & 1,1 & 161 & 1,2 & 179 & 1,3 & 222 \\
\hline
\end{tabular}

Uwagi: p - wskaźnik penetracji (składka/PKB w \%), g - wskaźnik gęstości (składka/per capita w USD), bd - brak danych.

Źródło: OECD data, https://stats.oecd.org/ [dostęp: 11.10.2021].

Wskaźniki penetracji i gęstości potwierdzają, że wydatki na ochronę ubezpieczeniową są zdecydowanie niższe w Polsce niż w wyróżnionych trzech krajach zachodnich UE oraz niższe niż np. w Czechach. Powyższe dane pokazują duży niedorozwój tego działu ubezpieczeń w Polsce na tle innych krajów.

W Polsce w dziale Il ubezpieczeń w latach 2011-2019 nastapił wzrost liczby zakładów ubezpieczeń do 34 w latach 2016-2019, po spadku do 30 w latach 2014-2015. Zmiany w liczbie zakładów ubezpieczeń wynikały zarówno z procesów konsolidacji poprzez fuzje i przejęcia - głównie z oddziaływania międzynarodowych ubezpieczeniowych grup kapitałowych operujacych na polskim rynku, jak również z faktu powstawania nowych firm ubezpieczeniowych.

W latach 2011-2015 w dziale Il ubezpieczeń utrzymuje się wysoki udział inwestycji zagranicznych w kapitale podstawowym firm ubezpieczeniowych (80-91\%), natomiast od 2016 r. następuje zmniejszenie i stabilizacja udziału na poziomie 67-69\% (w 2019 r.: 67,1\%).

Tabela 3. Udział zagranicznych inwestycji w kapitale podstawowym ubezpieczycieli oraz udział składki przypisanej brutto z firm o przeważającym kapitałem zagranicznym w Polsce w latach 2011-2019 (w \%)

\begin{tabular}{|l|c|c|c|c|c|c|c|c|c|}
\hline & 2011 & 2012 & 2013 & 2014 & 2015 & 2016 & 2017 & 2018 & 2019 \\
\hline $\begin{array}{l}\text { Udział zagranicznych inwestycji w kapitale } \\
\text { podstawowym ubezpieczycieli krajowych }\end{array}$ & 85,0 & 91,1 & 83,9 & 81,4 & 81,9 & 69,5 & 67,8 & 67,8 & 67,1 \\
\hline $\begin{array}{l}\text { Udział składki przypisanej brutto z firm } \\
\text { o przeważającym kapitale zagranicznym } \\
\text { w składce działu Il ubezpieczeń }\end{array}$ & 62,9 & 62,8 & 61,3 & 63,1 & 62,1 & 59,2 & 58,4 & 59,1 & 60,2 \\
\hline
\end{tabular}

Źródło: obliczenia własne na podstawie danych KNF (Biuletyn Roczny. Rynek ubezpieczeń za odpowiednie lata, ww.knf.gov.pl [dostęp: 11.12.2021]]). 
Natomiast udział składki przypisanej brutto z firm o przeważającym kapitale zagranicznym w składce działu Il ubezpieczeń nie ulegał większym zmianom, oscylując wokół $60 \%$.

Kolejna cechą polskiego rynku ubezpieczeń non-life jest znaczny i rosnący poziom jego koncentracji.

Tabela 4. Wskaźniki koncentracji rynku ubezpieczeń non-life w Polsce w latach 2011-2019

\begin{tabular}{|l|c|c|c|c|c|c|c|c|c|c|}
\hline & 2011 & 2012 & 2013 & 2014 & 2015 & 2016 & 2017 & 2018 & 2019 \\
\cline { 2 - 11 } & \multicolumn{8}{|c|}{ [w \% składki przypisanej brutto] } \\
\hline CR3 & 52,1 & 55,9 & 57,8 & 57,3 & 58,6 & 59,7 & 60,9 & 61,0 & 59,8 \\
\hline CR5 & 63,6 & 67,0 & 68,8 & 68,8 & 69,2 & 69,5 & 70,6 & 70,9 & 69,1 \\
\hline CR8 & 75,9 & 79,5 & 80,4 & 79,6 & 79,0 & 79,5 & 81,0 & 81,4 & 80,3 \\
\hline CR10 & 82,4 & 84,3 & 85,0 & 83,6 & 83,5 & 84,5 & 86,1 & 86,5 & 85,4 \\
\hline
\end{tabular}

Źródło: obliczenia własne na podstawie danych PIU, https://piu.org.pl/ [dostęp: 11.10.2021].

W badanym okresie wskaźnik koncentracji obrazujący udział trzech największych ubezpieczycieli w składce przypisanej brutto rynku ubezpieczeń non-life wzrósł o ponad 7 punktów procentowych i osiagnałł poziom niemal 60\%. Pozostałe wskaźniki koncentracji odnotowały również istotne wzrosty udziału w rynku. Rosnący poziom koncentracji rynku może wpływać na zmniejszenie jego konkurencyjności.

Tabela 5. Struktura składki przypisanej brutto w rozbiciu na główne linie biznesowe (grupy ubezpieczeń) w dziale ubezpieczeń non-life w latach 2011-2019

\begin{tabular}{|l|c|c|c|c|c|c|c|c|c|}
\hline \multirow{2}{*}{\multicolumn{1}{|c|}{ Linie biznesowe ubezpieczeń }} & \multicolumn{7}{|c|}{ Składka przypisana brutto (w \%) } \\
\cline { 2 - 11 } & 2011 & 2012 & 2013 & 2014 & 2015 & 2016 & 2017 & 2018 & 2019 \\
\hline Komunikacyjne & 56,8 & 55,5 & 51,8 & 50,8 & 50,3 & 56,9 & 59,4 & 58,0 & 55,4 \\
\hline Majątkowe (rzeczowe) & 19,0 & 20,0 & 21,0 & 20,0 & 20,0 & 17,1 & 16,0 & 16,8 & 17,0 \\
\hline Wypadkowe i zdrowotne & 6,6 & 6,7 & 7,2 & 7,7 & 7,6 & 6,3 & 5,8 & 6,1 & 6,4 \\
\hline Finansowe & 7,1 & 6,1 & 7,3 & 8,4 & 6,4 & 4,8 & 4,3 & 4,3 & 4,7 \\
\hline Odpowiedzialności cywilnej ogólnej & 5,7 & 6,6 & 7,2 & 7,4 & 7,1 & 5,8 & 5,2 & 5,4 & 5,6 \\
\hline $\begin{array}{l}\text { M.A.T. (transportowe, morskie, statków } \\
\text { powietrznych) }\end{array}$ & 1,2 & 1,2 & 1,3 & 1,4 & 1,1 & 1,0 & 0,8 & 0,9 & 1,1 \\
\hline Pozostałe & 3,6 & 3,9 & 4,2 & 4,3 & 7,5 & 8,1 & 8,5 & 8,5 & 9,8 \\
\hline
\end{tabular}

Źródło: obliczenia własne na podstawie danych PIU, https://piu.org.pl/ [dostęp: 11.10.2021].

Pod względem linii biznesowych polski rynek ubezpieczeń non-life jest silnie zdominowany przez ubezpieczenia komunikacyjne. Udział składki przypisanej brutto w tych ubezpieczeniach w całym badanym okresie kształtował się na poziomie powyżej 50\% składki tego działu ubezpieczeń, a w roku 2017 zbliżył się do 60\%, co wynika zarówno z dynamicznego wzrostu liczby samochodów, jak i z podwyższenia stawek taryfowych w tych ubezpieczeniach. Ubezpieczenia majątkowe pozostawały na drugim miejscu, ale z tendencją spadkową: z 21,0\% w 2013 roku do 17,0\% w roku 2019. Udział ubezpieczeń odpowiedzialności cywilnej ogólnej od 2014 roku zmniejszył się z 8,3\% do 5,6\% w 2019 roku. Bez wyraźnej tendencji rozwojowej pozostawał udział ubezpieczeń odpowiedzialności cywilnej i ubezpieczeń M.A.T. W sumie dwie linie biznesowe, tj. ubezpieczenia 
komunikacyjne oraz ubezpieczenia majątkowe, generowały blisko $3 / 4$ składki przypisanej brutto tego działu ubezpieczeń.

Tabela 6. Lokaty, ich rentowność oraz wyniki finansowe w dziale Il ubezpieczeń w Polsce w latach 2011-2019

\begin{tabular}{|l|c|c|c|c|c|c|c|c|c|}
\hline \multicolumn{1}{|c|}{ Wyszczególnienie } & 2011 & 2012 & 2013 & 2014 & 2015 & 2016 & 2017 & 2018 & 2019 \\
\hline Dochód z lokat (mln zł) & 3720 & 3703 & 5745 & 3815 & 2992 & 2827 & 2883 & 3051 & 3475 \\
\hline Stan lokat (mln zł) & 45461 & 52048 & 53336 & 59072 & 62523 & 63154 & 72133 & 76966 & 79542 \\
\hline Rentowność lokat (w \%) & 8,2 & 7,1 & 10,8 & 6,5 & 4,8 & 4,5 & 3,9 & 4,0 & 4,4 \\
\hline $\begin{array}{l}\text { Wynik finansowy netto } \\
\text { (mln zł) }\end{array}$ & 3087 & 3387 & 6109 & 3673 & 2567 & 1994 & 3505 & 4153 & 4640 \\
\hline
\end{tabular}

Źródło: obliczenia własne na podstawie danych PIU, https://piu.org.pl/ [dostęp: 6.08.2021].

Dane z tabeli 6. pokazuja, że w końcu 2019 roku ubezpieczyciele z działu ubezpieczeń non-life zainwestowali ponad 79,5 mld zł, osiągając dochód z lokat ponad 3,4 mld zł. W całym badanym okresie rentowność lokat tego działu ubezpieczeń wykazała stałą tendencję malejąca: z 10,8\% w 2013 roku do 4,4\% w 2019 roku. Malejący trend rentowności wiązał się głównie z obniżkami stóp procentowych dokonywanymi przez NBP (Radę Polityki Pieniężnej). Wyniki finansowe netto nie wykazały jednolitej tendencji zmian, osiagając najwyższą wartość w 2013 roku (ponad 6,1 mld zł), a najniższa - w 2016 roku (blisko 2 mld zł), na co wpływ miały wyniki techniczne ubezpieczycieli oraz dochody z lokat.

\section{Efektywność ubezpieczycieli - charakterystyka wybranych badań empirycznych na świecie}

Szeroki przegląd badań nad efektywnością ubezpieczycieli zawierają w szczególności publikacje zespołów Cummins i Weiss $(2001)^{9}$ oraz Eling i Luhnen $(2009){ }^{10}$. Jak wskazują autorzy, badania te w większości obejmują rozwinięte rynki ubezpieczeniowe w USA oraz w Europie, a także rozwijające się rynki w Azji. Większość badań na rynkach rozwiniętych dotyczyła efektywności kosztowej, a w ograniczonym zakresie również efektywności zysków. Podkreśla się, że przedmiotem zainteresowań autorów w analizowanych publikacjach są takie problemy jak:

1) kwestie metodologiczne w szacowaniu efektywności - wybór metody parametrycznej lub metody nieparametrycznej, np. DEA (a w ramach parametrycznej stochastycznej analizy granicznej - metody SFA [Stochastic Frontier Approach], DFA [Distribution-Free Approach] względnie TFA [Thick Frontier Approach]),

2) wybór funkcji typu Cobb-Douglasa czy translogarytmicznej funkcji kosztów wraz z określeniem czynników produkcji i produktów do funkcji granicznej,

3) określenie dziedzin zastosowań pomiaru efektywności w ubezpieczeniach.

Wyniki oszacowań efektywności kosztowej ubezpieczycieli cechują się zróżnicowaniem w zależności od badanych rynków ubezpieczeniowych oraz przyjętych metod badawczych.

9. J.D. Cummins, M.A. Weiss, op. cit., s. 36-43.

10. M. Eling, M. Luhnen, Efficiency in the international insurance industry: A cross-country comparison, "Journal of Banking \&Finance" 2009, №. 34[?]): s. 1497-1509. 
Fen i współpracownicy ${ }^{11}$ (2008) badali efektywność kosztów oraz efektywność zysków metoda SFA na 14 europejskich rynkach ubezpieczeniowych w latach 1995-2001. Autorzy wykazali występowanie malejących kosztów funkcjonowania badanych firm ubezpieczeniowych oraz zauważyli, że wzrost liczby fuzji i przejęć skutkował wysoką efektywnością zysków w Europie. Wyniki badań autorów pokazały, że na efektywność istotny wpływ miały wielkość i udział w rynku badanych firm.

Kasman i Turgutlu ${ }^{12}$ (2011) dokonali oceny efektywności kosztowej SFA firm prowadzacych ubezpieczenia non-life na jednolitym rynku ubezpieczeniowym UE w latach 1995-2005 w kontekście rosnącej konkurencyjności rynku. Autorzy określili, że przeciętna efektywność kosztów kształtowała na poziomie ponad 88\%, natomiast dla 9 firm na rynku w Polsce przeciętna efektywność kosztowa wyniosła blisko 97\% w 2005 roku.

Choi i Elyasiani ${ }^{13}$ (2011), badając metodą SFA firmy z kapitałem zagranicznym na rynku ubezpieczeń non-life w USA, określili ich efektywność kosztów na poziomie blisko 80\%. Autorzy wykazali, że firmy te charakteryzowała wyższa efektywność kosztów i przychodów w porównaniu z firmami o kapitale krajowym.

Cummins i Xie ${ }^{14}$ (2013), wykorzystując metodę DEA, zanalizowali 781 zakładów ubezpieczeń w dziale ubezpieczeń non-life w latach 1995-2009 w USA. Wyniki ich badań wykazały dla firm m.in. przeciętną efektywność kosztów w wysokości 51\%, a przeciętna nieefektywność zysków wyniosła 0,63\%.

Ferro i Leon ${ }^{15}$ przebadali metoda SFA efektywność kosztową 73 firm ubezpieczeń non-life w Argentynie w latach 2009-2014, wykorzystując model Cobb-Douglasa oraz translogarytmiczny. Autorzy przeprowadzili badanie w dwóch wariantach. W pierwszym przyjęto założenie dla składnika nieefektywności $u_{i}$, że nie zmienia się w czasie (the time-invariant inefficiency), a w drugim, że zmienia się w czasie (the time-variant inefficiency). Przeciętną efektywność techniczną ubezpieczycieli autorzy oszacowali na poziomie $42-43 \%$.

Barros i Wanke ${ }^{16}$, stosujac funkcję kosztów metody SFA, zanalizowali ubezpieczycieli działu ubezpieczeń non-life Angoli i Mozambiku w latach 2002-2012. Autorzy wykazali, że średnie wartości efektywności kosztowej ubezpieczycieli kształtowały się w granicach 30-44\%.

Alhassan i Biepke ${ }^{17}$, wykorzystując roczne dane z 80 zakładów ubezpieczeń non-life w Afryce południowej w latach 200?-2012 oraz stosujacc techniki metody SFA, oszacowali ich efektywność kosztów oraz efektywność zysków. Autorzy określili przeciętną efektywność kosztów ubezpie-

11. P. Fenn, D. Vencappa, S. Diacon, P. Klumpes, C. O'Brien, Market structure and the efficiency of European insurance companies: a stochastic frontier analysis, "Journal of Banking and Finance" 2008, No. 32(1), s. 86-100.

12. A. Kasman, E. Turgutlu, Performance of European insurance firms in the single insurance market, "International Review of Applied Economics" 2011, Vol. 25, Issue 3, s. 369-374.

13. B.P. Choi, E. Elyasiani, Foreign-owned insurer performance in the US property-liability markets, "Applied Economics" 2011, Vol. 43, No. 3, s. 291-306.

14. J.D. Cummins, X. Xie, Efficiency, productivity, and scale economies in The U.S. property-liability insurance industry, "Journal of Productivity Analysis" 2011,Vol. 39, No. 2, s.131-13?.

15. G. Ferro, S. Leon, A Stochastic Frontier Analysis of Efficiency in Argentina's Non-Life Insurance Market, "Geneva Papers on Risk and Insurance - Issue and Practice" 2018, Vol. 43, Issue 1, No ?, s. 158-174.

16. C. Barros, P. Wanke, Cost Efficiency of African Insurance Companies using a Finite Mixture Model, "SAJEMS" 2016, Vil. 19, № 1, s.75-78.

17. A.L. Alhassan, N. Biepke, Competition and efficiency in the non-life insurance market in South Africa, "Journal of Economic Studies" 2016, Vol. 43, Issue 6, s.894-896. 
czycieli na poziomie ponad 80\%, a przeciętną efektywność zysków - na ponad 45\%. Potwierdzili również występowanie konkurencji monopolistycznej na tym rynku, stosując model Panzar-Rosse.

Grmanová i Pukała ${ }^{18}$ dokonali analizy porównawczej efektywności firm ubezpieczeniowych w dziale ubezpieczeń życiowych operujących w Czechach i w Polsce, wykorzystując model DEA. Przedmiotem badania było 17 komercyjnych firm w Czechach i 25 firm komercyjnych w Polsce w 2014 roku. Przeciętna efektywność ubezpieczycieli w Polsce wyniosła 0,6182, a w Czechach 0,5235.

Kozak ${ }^{19}$ oszacował efektywność kosztów dla 29 firm ubezpieczeniowych operujacych w dziale ubezpieczeń non-life w Polsce w latach 2002-2016. Do oszacowania efektywności kosztowej autor zastosował metodę SFA. Wyniki jego badania pokazały dużą zmienność efektywności ubezpieczycieli, tj. od 62,5\% w 2002 roku do 65,8\% w 2007 roku i 59,4\% w roku 2016.

W kolejnym badaniu autor ${ }^{20}$ objął analizą 29 zakładów ubezpieczeń funkcjonujących na rynku ubezpieczeń non-life w latach 2002-2017 w Polsce, w tym 21 spółek akcyjnych i 8 towarzystw ubezpieczeń wzajemnych. Oszacowań efektywności kosztów ubezpieczycieli autor dokonał metodą SFA. Badania wykazały, że przeciętna efektywność spółek akcyjnych wyniosła 51,2\%, a towarzystw ubezpieczeń wzajemnych $-42,5 \%$.

\section{Metodyka badań i dane statystyczne}

W omawianej analizie wykorzystano techniki metody SFA. Badając efektywność techniczną zakładów ubezpieczeń, zastosowano podejście zorientowane na nakłady (input-oriented approach], co oznacza, że ubezpieczyciel minimalizuje koszty lub maksymalizuje zyski poprzez wybór odpowiedniej kombinacji (technologii) swoich nakładów i produktów (efektu), w zależności tylko od cen tych nakładów i produktów ${ }^{21}$. Innymi słowy: efektywność firmy zależy od jej zdolności do minimalizacji kosztów lub maksymalizacji zysków, jej zdolności do wytworzenia danej ilości produktu (produktów) przy minimalnych kosztach oraz optymalnej kombinacji nakładów z uwzględnieniem dostępnych cen. Przy wyborze zmiennych modelu SFA reprezentujaccego produkt (y) kierowano się podejściem wartości dodanej (podejściem produkcyjnym) ${ }^{22}$, które uznaje produkty za ważne, jeśli wnoszą one wartość dodaną z punktu widzenia kosztów operacyjnych. W podejściu tym przyjmuje się, że ubezpieczyciel świadczy trzy główne usługi poprzez swoje produkty. Pierwsza usługę, tj. ochronę ubezpieczeniową (the risk pooling / risk-bearing function ), tworząc wartość dodana poprzez zarządzanie ryzykami (przejętymi od ubezpieczonych), pobierając składki od ubezpieczających i redystrybuując je wśród tych ubezpieczonych, którzy doznali szkód. W drugiej roli ubezpieczyciele tworzą wartość dodaną dla swoich ubezpieczonych poprzez świadczenie takich usług finansowych jak: projektowanie programów pokrycia ubezpieczeniowego (w ubezpieczeniach

18. E. Grmanová, R. Pukała, Efficiency of insurance companies in the Czech Republic and Poland, "Oeconomia Copernicana" 2018, No. 9[1], s. ?7-80.

19. S. Kozak, Efficiency of non-life insurance companies and its determinants, "Acta Scientarum Polonorum Oeconomia" 2018, nr 1? (4), s. 90-92.

20. S. Kozak, Forma prawna zakładu ubezpieczeń majqtkowych a jego efektywność, „Studia Ekonomiczne. Zeszyty Naukowe Uniwersytetu Ekonomicznego w Katowicach" 2019, nr 387, s. 78-79.

21. J.D. Cummins, M.A. Weiss, Analyzing Firm PerformanceE, s. 4-6.

22. M. Eling, M. Luhnen, Efficiency in the international insurance industry: A cross-country comparison, "Journal of Banking \&Finance" 2009, No. 34[?], s.1497-1509. 
non-life), czy długoterminowego planowania finansowego w programach ubezpieczeń na życie. W trzeciej roli ubezpieczyciele tworzą wartość dodaną, występując jako pośrednicy finansowi inwestujący czasowo wolne składki ubezpieczeniowe w instrumenty rynku finansowego, a także wypłacając odszkodowania i świadczenia oraz pokrywając wydatki administracyjne.

Jako przybliżoną miarę pełnienia funkcji ochrony ubezpieczeniowej przyjęto wartość wypłaconych odszkodowań i świadczeń na udziale własnym $(y)$. Z pełnieniem trzeciej funkcji przez ubezpieczycieli, jak wskazuje się w literaturze ${ }^{23}$, skorelowane są wartości wypłat na odszkodowania i świadczenia.

Za literatura przedmiotu ${ }^{24}$ przyjęto trzy podstawowe czynniki produkcji, tj.: pracę i usługi biznesowe, kapitał dłużny i kapitał. Jako przybliżoną miarę ceny pracy i usług biznesowych przyjęto iloraz kosztów administracyjnych i wypłaconych prowizji ubezpieczeniowych pomniejszonych o prowizje reasekuracyjne (koszty działalności ubezpieczeniowej na udziale własnym) do aktywów, ceny kapitału dłużnego - iloraz dochodu z lokat (inwestycji) do rezerw techniczno-ubezpieczeniowe brutto, a ceny kapitału - iloraz wyniku finansowego netto do kapitałów własnych. Wszystkie wartości pieniężne przeliczono, wykorzystując deflatora, tj. CPI przy bazie z roku 2011.

Wykorzystując ujęcie zaproponowane w publikacjach, np. Delis i współpracownicy ${ }^{25} \mathrm{czy}$ Alhassana i Biepke ${ }^{26}$, określono bazowy model funkcji kosztów modelu granicznego:

$$
C_{i t}=f\left(y_{i t}, w_{i t}, e_{i t}\right)
$$

gdzie:

$C_{i t}-$ koszty zakładu ubezpieczeń „i” w roku „t”

$y_{\text {it }}$ - wektor produktów zakładu ubezpieczeń

$w_{i t}$ - ceny czynników produkcji (nakładów)

$e_{i t}$ - zmienna losowa wyrażająca wpływ niezależnych składników losowych

$i$ - oznacza numer zakładu ubezpieczeń $(i=1,2, \ldots, N)$

$t$ - numer roku $(t=1,2, \ldots, T)$

Przyjmuje się, że zmienna losowa $e_{i t}$ zawiera następujące dwa składniki:

$$
e_{i t}=u_{i t}+v_{i t}
$$

gdzie:

$u_{i t}$ - niezależna zmienna losowa, asymetryczna i dodatnia, modelująca nieefektywność;

$v_{i t}$ - niezależna zmienna losowa, symetryczna względem zera i odzwierciedlająca wpływ czynni-

ków przypadkowych oraz błędów pomiaru.

Przyjmuje się założenie, że składnik wyrażający nieefektywność $\left(u_{i t}\right)$ jest zmienną losową niezależną o jednostronnym rozkładzie normalnym nieujemnym, uciętym przy zero, bądź o rozkładzie

23. J.D. Cummins, M.A. Weiss, Analyzing Firm PerformanceE, s. 31-36.

24. Ibidem.

25. M.D. Delis, A. Koutsomanoli-Fillipaki, Ch. K. Staikouras, op.cit., s. 9.

26. A.L. Alhassan, N. Biepke, Competition and efficiency in the non-life insurance market in South Africa, "Journal of Economic Studies" 2016, Vol. 43 Issue 6, s. 888-890. 
wykładniczym; natomiast zmienna losowa $v_{i t}$ jest niezależną zmienną o rozkładzie normalnym symetrycznym (ze średnią równą zero oraz stałej wariancji).

Dokonując logarytmicznej transformacji równania (1), otrzymano następujące wyrażenie:

$$
\ln \left(C_{i t}\right)=f\left(\ln y_{i t} ; \ln w_{i t}\right)+\ln u_{i t}+\ln v_{i t} .
$$

Przy określaniu efektywności zysków przyjęto podejście efektywności alternatywnego zysku (alternative profit efficiency) ${ }^{27}$, które zakłada występowanie rynku o konkurencji niedoskonałej28, w przeciwieństwie do podejścia efektywności granicznej zysku standardowego, wykorzystywanego na rynkach o konkurencji doskonałej. W podejściu alternatywnym uwzględnia się różnice w jakości usług świadczonych przez ubezpieczycieli oraz w zakresie informacji o cenach produktów ubezpieczeniowych. Zakłada się, że ubezpieczyciele wybierają taką kombinację ilości produktów (y) oraz cen nakładów czynników produkcji (w), która zapewni maksymalizację ich zysków.

Model ogólny funkcji zysków określa się w ten sposób, że w równaniu (1) oraz (3) zastępuje się zmienna $C_{i t}$ zmienną $\pi_{i t}$ będąca zyskiem netto, tj.:

$$
\pi_{i t}=f\left(y_{i t}, w_{i t}, e_{i t}\right)
$$

oraz

$$
\ln \left(\pi_{i t}+\theta\right)=f\left(\ln y_{i t} ; \ln w_{i t}\right)-\ln u_{i t}+\ln v_{i t}
$$

gdzie:

$\theta$ - jest stała (tj. największą bezwzględną wartością z ujemnych wartości zwiększoną o jeden) dodana do zysku (straty) każdego zakładu ubezpieczeń w celu umożliwienia transformacji logarytmicznej wartości ujemnych.

W badaniu efektywności kosztów (oraz zysków) wykorzystano translogarytmiczną funkcję kosztów ${ }^{29}$. W modelu efektywności zysków wymienia się tc na wynik finansowy netto $\pi^{30}$; funkcja kosztów przyjęła następująca postać funkcyjną:

27. Por. np. M.D. Delis, A. Koutsomanoli-Fillipaki, Ch.K. Staikouras, op.cit., s. 6-8, a także m.in. R. Wicaksono, T. Mulyaningsih, Does ownership structure matter? A cost efficiency study of life insurance firms in Indonesia, "Bulletin of Monetary Economics and Banking" 2019, Vol. 22, No. 3, s. 371-373.

28. Por. K. Ortyński, M. Pypeć, Competition in the Polish non-life insurance market, [w:] Competitiveness and Economic Development in Europe. Prospects and Challenges, [red.] S.I. Bukowski, A. Hyz, M.B. Lament, Routledge Taylor \& Francis Group, London-New York 2021, s. 205-216, gdzie wykazano występowanie konkurencji niedoskonałej (monopolistycznej) na polskim rynku ubezpieczeń non-life.

29. M. Eling, M. Luhnen, 2009, op. cit., s. 1508-1509 oraz A.L. Alhassan, N. Biepke, op.cit., s. 889-890.

30. Dla funkcji zysków składnik nieefektywności zamienia się w równaniu (6) na „-u”. 


$$
\begin{aligned}
& \ln \left(\frac{t c}{w_{1}}\right)_{i t}=a_{0}+a_{1} \ln (y)_{i t}+0,5 a_{2}(\ln y)_{i t}^{2}+ \\
& +\beta_{1} \ln \left(\frac{w_{2}}{w_{1}}\right]_{i t}+\beta_{2} \ln \left(\frac{w_{3}}{w_{1}}\right)_{i t}+0,5 \beta_{3}\left(\ln \frac{w_{2}}{w_{1}}\right)_{i t}^{2}+ \\
& +0,5 \beta_{4}\left(\ln \frac{w_{3}}{w_{1}}\right)_{i t}^{2}+\beta_{5} \ln \left(\frac{w_{2}}{w_{1}}\right)_{i t} \ln \left(\frac{w_{3}}{w_{1}}\right)_{i t}+\gamma_{1} \ln (y)_{i t} \ln \left(\frac{w_{2}}{w_{1}}\right)_{i t}+ \\
& +\gamma_{2} \ln (y)_{i t} \ln \left(\frac{w_{3}}{w_{1}}\right)_{i t}+v_{i t}+u_{i t}
\end{aligned}
$$

gdzie:

tc - koszty działalności ubezpieczeniowej na udziale własnym

$y$ - wypłacone odszkodowania i świadczenia na udziale własnym

$w_{1}$ - cena pracy i usług biznesowych

$w_{2}$ - cena kapitału dłużnego

$w_{3}$ - cena kapitału

$a, \beta, \gamma$-parametry modelu (6).

W celu zapewnienia liniowej homogeniczności (jednorodności) translogarytmicznej funkcji kosztów względem cen czynników produkcji dokonano normalizacji (podzielenia) kosztu (tc) (a także zysku $(\pi+\theta)$ ) oraz cen $\left(w_{2}\right.$ i $\left.w_{3}\right)$ przez wybraną cenę, w tym przypadku przez $w_{1}$.

Występowanie nieefektywności w modelu bada się wskaźnikiem wariancji y, tj. $\gamma=\frac{\sigma_{u}^{2}}{\left(\sigma_{u}^{2}+\sigma_{v}^{2}\right)}$. Wskaźnik ten określa udział wariancji (zmienności) zmiennej losowej $u_{i t}$ w wariancji (zmienności) zmiennej losowej $e_{i t}$. Wskaźnik ten przyjmuje wartości między 0 a 1, a wartości bliższe 1 oznaczaja, że większość odchyleń od granicznej (optymalnej) efektywności może się wiązać z nieefektywnością zarządzania. Wielkości efektywności wyznaczono, stosując formułę ${ }^{31}$ :

$$
\mathrm{TE}_{i t}=\exp \left\{-\hat{u}_{i t}\right\}(\mathrm{i}=1, \ldots, \mathrm{N} ; \mathrm{t}=1, \ldots, \mathrm{T}),
$$

gdzie:

$\mathrm{TE}_{i t}-$ techniczna efektywność.

Wartości efektywności mieszczą się w obszarze między 0 a 1, bliższe 1 oznaczają wyższa efektywność.

Tabela ?. Zmienne podstawowe nietransformowane w modelach funkcji kosztów i zysków

\begin{tabular}{|l|l|}
\hline \multicolumn{1}{|c|}{ Zmienne } & \multicolumn{1}{c|}{ Opis } \\
\hline$t c$ & Koszty działalności ubezpieczeniowej na udziale własnym \\
\hline$\pi$ & Wynik finansowy netto \\
\hline$y$ & Odszkodowania i świadczenia wypłacone na udziale własnym \\
\hline$w_{1}-$ cena pracy & Wskaźnik kosztów działalności ubezpieczeniowej na udziale własnym do aktywów \\
\hline$w_{2}-$ cena kapitału dłużnego & Wskaźnik dochodów z inwestycji (lokat) do rezerw techniczno-ubezpieczeniowych brutto \\
\hline$w_{3}-$ cena kapitału własnego & Wskaźnik wyniku finansowego netto do kapitału własnego \\
\hline
\end{tabular}

Źródło: opracowanie własne.

31. G.E. Battese, T.J. Coelli, A model for technical inefficiency effects in a stochastic frontier production function for panel data, "Empirical Economics" 1995, No. 20, s. 326-327. 
W badaniu wykorzystano informacje z 18 firm ubezpieczeniowych (spółek akcyjnych) działu II ubezpieczeń w Polsce za lata 2011-2019. Firmy te przez wszystkie 9 lat udostępniały swoje dane statystyczne do „Raportów rocznych” Polskiej lzby Ubezpieczeń (PIU) w Warszawie ${ }^{32}$. Składka przypisana brutto badanych firm ubezpieczeniowych stanowiła w 2019 roku ponad 85\% składki przypisanej brutto tego działu ubezpieczeń. Zbiór wykorzystanych danych stanowił panel zbilansowany danych rocznych.

W opracowaniu estymację parametrów translogarytmicznej funkcji kosztów i funkcji zysków (równanie 6) modelu SFA oraz oszacowanie składnika losowego $\left(v_{i t}\right)$ i część określającą nieefektywność zmienną w czasie (the time-varying inefficiency) $\hat{u}_{i t}$, wykonano metodą największej wiarygodności, wykorzystujac oprogramowanie $\mathrm{R}^{33}$, a wartości efektywności wyznaczono na podstawie równania?.

Ponadto do obliczeń wykorzystano Microsoft Excel.

Tabela 8. Statystyki opisowe zmiennych nietransformowanych

\begin{tabular}{|c|c|c|c|c|c|}
\hline Zmienne & Wartość średnia & $\begin{array}{c}\text { Odchylenie } \\
\text { standardowe }\end{array}$ & $\begin{array}{l}\text { Wartość } \\
\text { minimalna }\end{array}$ & $\begin{array}{c}\text { Wartość } \\
\text { maksymalna }\end{array}$ & $\begin{array}{c}\text { Liczba } \\
\text { obserwacji }\end{array}$ \\
\hline Koszty (tys. zł] & 365356 & 590794 & 1144 & 2879436 & 162 \\
\hline Zysk netto (tys. zł] & 187336 & 625127 & -139348 & 4880229 & 162 \\
\hline Produkt & \multirow{2}{*}{696480} & \multirow{2}{*}{1316534} & \multirow{2}{*}{10} & \multirow{2}{*}{6653999} & \multirow{2}{*}{162} \\
\hline$y$ (tys. zł] & & & & & \\
\hline $\begin{array}{l}\text { Ceny czynników } \\
\text { produkcji }\end{array}$ & \multirow[b]{2}{*}{0,14371993} & \multirow[b]{2}{*}{0,091983239} & \multirow[b]{2}{*}{0,017874872} & \multirow[b]{2}{*}{0,594436364} & \multirow[b]{2}{*}{162} \\
\hline$w_{1}$ & & & & & \\
\hline$w_{2}$ & 0,0479221849 & 0,047455831 & $-0,014742597$ & 0,373641275 & 162 \\
\hline$w_{3}$ & 0,04840016 & 0,174468908 & $-0,97386842$ & 0,416512606 & 162 \\
\hline
\end{tabular}

Źródło: opracowanie własne na podstawie danych PIU i GUS.

\section{Wyniki badań empirycznych}

Przy estymacji modelu SFA dla funkcji kosztowej i funkcji zysków metodą największej wiarygodności przyjęto założenie, że zmienna losowa $u_{i t}$ jest zmienną o rozkładzie wykładniczym.

Tabela 9. prezentuje wyniki estymacji dla standardowego modelu SFA translogarytmicznej funkcji kosztów oraz funkcji zysków (równanie 6) wraz z oszacowanymi wariancjami dwóch części składnika resztowego, tj. $\sigma_{v}^{2}$ oraz $\sigma_{u}^{2}$, a także wskaźnika wariancji $\gamma$, które są niezbędne do analizy efektywności.

32. Przedmiotem badania były dane następujących zakładów ubezpieczeń: Allianz Polska SA, Aviva Ogólne SA, Compensa SA, DAS SA, Ergo Hestia SA, Euler Hermes SA, Europa SA, Generali SA, Inter Polska SA, Interrisk SA, KUKE SA, Link 4 SA, Partner SA, PTR SA, PZU SA, Signal Iduna Polska SA, Uniqa SA, Warta SA.

33. Oprogramowanie R wykorzystało m.in. publikacje: G.E. Battese, T.J. Coelli, Frontier production functions, technical efficiency and panel data: With application to paddy farmers in India, "Journal of Productivity Analysis" 1992, No. 3, s.153-169 oraz G.E Battese, T.J. Coelli, A model for technical inefficiency effects in a stochastic frontier production function for panel data, "Empirical Economics" 1995, №. 20, s. 325-332. 
Tabela 9. Wyniki oszacowań modelu SFA dla funkcji kosztowej i funkcji zysków

\begin{tabular}{|c|c|c|c|c|c|c|c|}
\hline \multirow{2}{*}{ Zmienne } & \multirow{2}{*}{ Parametry } & \multicolumn{3}{|c|}{ Efektywność kosztowa } & \multicolumn{3}{|c|}{ Efektywność zysków } \\
\hline & & Estymatory & SD & t-value & Estymatory & SD & t-value \\
\hline wolny wyraz & $a_{0}$ & $-4,770$ & 8,026 & $-0,594$ & 39,716 & 6,165 & 6,442 \\
\hline $\ln (y)_{i t}$ & $a_{1}$ & 0,479 & 0,379 & 1,265 & $-2,412$ & 0,286 & $-8,422$ \\
\hline $0,5(\ln y)_{\text {it }}^{2}$ & $a_{2}$ & 0,079 & $x$ & $x$ & 0,045 & 0,002 & 27,000 \\
\hline $\ln \left(\frac{\mathrm{W}_{2}}{\mathrm{~W}_{1}}\right)_{\text {it }}$ & $\beta_{1}$ & 1,401 & 1,131 & 1,238 & $-4,030$ & 0,720 & $-5,598$ \\
\hline $\ln \left(\frac{\mathrm{w}_{3}}{\mathrm{w}_{1}}\right)_{\text {it }}$ & $\beta_{2}$ & 9,837 & 4,157 & 2,366 & 1,667 & 3,171 & 0,526 \\
\hline $0,5\left(\ln \frac{\mathrm{w}_{2}}{\mathrm{w}_{1}}\right)_{i t}^{2}$ & $\beta_{3}$ & 0,492 & 0,464 & 1,061 & 1,044 & 0,245 & 4,263 \\
\hline $0,5\left(\ln \frac{\mathrm{w}_{3}}{\mathrm{w}_{1}}\right)_{i t}^{2}$ & $\beta_{4}$ & 0,120 & 0,468 & 0,255 & $-5,986$ & 0,252 & $-23,778$ \\
\hline $\ln \left(\frac{\mathrm{w}_{2}}{\mathrm{w}_{1}}\right)_{i t} \ln \left(\frac{\mathrm{w}_{3}}{\mathrm{w}_{1}}\right)_{i t}$ & $\beta_{5}$ & $-0,223$ & 0,416 & $-0,535$ & $-0,263$ & 0,206 & $-1,273$ \\
\hline $\ln (y)_{i t} \ln \left(\frac{w_{2}}{w_{1}}\right)_{i t}$ & $\gamma_{1}$ & $-0,030$ & 0,044 & $-0,681$ & 0,235 & 0,032 & 7,252 \\
\hline $\ln (y)_{i t} \ln \left(\frac{w_{3}}{w_{1}}\right)_{i t}$ & $V_{2}$ & $-0,487$ & 0,183 & $-2,669$ & 0,716 & 0,147 & 4,866 \\
\hline sigma u2 & & 0,186 & 0,040 & 4,619 & 0,037 & 0,008 & 4,594 \\
\hline sigma v2 & & 0,091 & $x$ & $x$ & 0,011 & $x$ & $x$ \\
\hline \multicolumn{5}{|c|}{$\begin{array}{l}\text { test LR: sigmau2=0 (nieefektywność nie wpływa na model); } \\
\text { HO: sigmau2=0; } \\
\text { wartość testu LR: } 47,698 \text { przy } 11 \text { stopniach swobody } \\
\text { z p-value: } 1 \text {; } \\
\text { wartość krytyczna chi2=19,675 przy a=0,05; }\end{array}$} & \multicolumn{3}{|c|}{$\begin{array}{l}\text { test LR: sigmau2=0 ( } \text { nieefektywność nie } \\
\text { wpływa na model); } \\
\text { HO: sigmau2=0; } \\
\text { wartość testu LR: } 23,659 \text { przy } 11 \text { stopniach } \\
\text { swobody, z p-value: 0,986; } \\
\text { wartość krytyczna chi2=19,675 przy a=0,05; }\end{array}$} \\
\hline \multicolumn{5}{|c|}{ logarytm wiarygodności: -115,172 } & \multicolumn{3}{|c|}{ logarytm wiarygodności:37,591 } \\
\hline \multicolumn{5}{|c|}{ wartość parametru wariancji ү: 0,671 } & \multicolumn{3}{|c|}{ wartość parametru wariancji ү: 0,771 } \\
\hline \multicolumn{5}{|c|}{ przeciętna efektywność kosztowa: 0,6958 } & \multicolumn{3}{|c|}{ przeciętna efektywność zysków: 0,8382 } \\
\hline
\end{tabular}

Legenda: SD - odchylenie standardowe; $\mathrm{X}$ - brak danych.

Źródło: obliczenia własne.

Na poprawność oszacowanych modeli wskazuje statystyka testowa ilorazu wiarygodności LR - jest ona większa niż wartość krytyczna testu chi2, co oznacza, że należy odrzucić hipotezę zerową i można przyjąć, że nieefektywność wpływała na modele.

Wartość parametru wariancji $ү$ (odpowiednio 0,671 dla funkcji kosztów oraz 0,771 dla funkcji zysku) wskazuje, że w strukturze składnika resztowego dominuje składnik reprezentujacy nieefektywność. Innymi słowy: zastosowana metoda SFA lepiej określa nieefektywność badanej grupy ubezpieczycieli niż metody deterministyczne.

Przeciętna efektywność kosztów wyniosła 0,6958, co sugeruje, że przeciętny ubezpieczyciel w dziale ubezpieczeń non-life ponosi o ponad 30,4\% relatywnie wyższe koszty w stosunku do ubezpieczyciela stosującego zasady tzw. best practice.

Przeciętna efektywność zysków wyniosła 0,8382, co wskazuje, że przeciętny ubezpieczyciel osiaggał o ponad $16 \%$ niższe zyski niż możliwe do uzyskania, przy stosowaniu optymalnych proporcji nakładów czynników produkcji z uwzględnieniem ich cen rynkowych. Na efektywność zysków wpływaja zarówno ceny produktów ubezpieczeniowych, jak i dochodowość lokat. 
Tabela 10. Przeciętna efektywność kosztowa i efektywność zysków w latach 2011-2019

\begin{tabular}{|c|c|c|c|c|}
\hline \multirow{2}{*}{ Lata } & \multicolumn{2}{|c|}{ Efektywność kosztów } & \multicolumn{2}{c|}{ Efektywność zysków } \\
\cline { 2 - 5 } & Wartość średnia & Odchylenie standardowe & Wartość średnia & Odchylenie standardowe \\
\hline 2011 & 0,7257 & 0,1739 & 0,8199 & 0,1279 \\
\hline 2012 & 0,7345 & 0,1749 & 0,8451 & 0,1234 \\
\hline 2013 & 0,6786 & 0,2000 & 0,8592 & 0,1065 \\
\hline 2014 & 0,7004 & 0,1759 & 0,8259 & 0,1600 \\
\hline 2015 & 0,6849 & 0,2000 & 0,8414 & 0,1122 \\
\hline 2016 & 0,6727 & 0,1777 & 0,8414 & 0,1241 \\
\hline 2017 & 0,6491 & 0,1616 & 0,8501 & 0,1119 \\
\hline 2018 & 0,6465 & 0,1598 & 0,8407 & 0,1233 \\
\hline 2019 & 0,6897 & 0,1668 & 0,8207 & 0,1234 \\
\hline Wartość przeciętna & 0,6958 & 0,1787 & 0,8382 & 0,1220 \\
\hline
\end{tabular}

Źródło: opracowanie własne.

W badanym okresie wystapiła relatywnie wyższa zmienność w efektywności kosztów niż w efektywności zysków, na co wskazują wartości odchyleń standardowych. Przeciętne wartości efektywności kosztów i efektywności zysków zmieniały się w czasie oraz wykazywały duże zróżnicowanie wśród firm.

Wskaźnik korelacji liniowej Pearsona między efektywnością kosztów a efektywnością zysków wyniósł 0,1552, co oznacza niską korelację. Sugeruje to, że efektywność kosztów niekoniecznie sprzyja efektywności zysków. W literaturze wskazuje się, że większy wpływ na efektywność zysków mogą mieć przychody niż koszty firm ${ }^{34}$.

Ze względu duże różnice w przychodach badanych firm przeprowadzono analizę zróżnicowania efektywności między dużymi i mniejszymi zakładami ubezpieczeń.

Tabela 11. Przeciętna efektywność kosztów i efektywność zysków ubezpieczycieli dużych i pozostałych

\begin{tabular}{|l|c|c|c|c|}
\hline & $\begin{array}{c}\text { Mniejsze firmy } \\
(\mathrm{n}=117)\end{array}$ & $\begin{array}{c}\text { Duże firmy } \\
{[\mathrm{n}=45)}\end{array}$ & $\begin{array}{c}\text { Różnica } \\
\text { efektywności }\end{array}$ & $\begin{array}{c}\text { test-u } \\
\mathrm{U} \sim \mathrm{N}(0,1]\end{array}$ \\
\hline Efektywność kosztów & 0,6897 & 0,7117 & $-0,022$ & $-0,8601^{* * *}$ \\
\hline Wariancja efektywności kosztów & 0,038683645 & 0,014565106 & & $\mathrm{x}$ \\
\hline Efektywność zysków & 0,8442 & 0,8228 & 0,0214 & $0,5273^{* * *}$ \\
\hline Wariancja efektywności zysków & 0,012611843 & 0,020889642 & & $\mathrm{x}$ \\
\hline
\end{tabular}

Hipoteza HO: wartość średnia (mniejsze firmy) = wartości średniej (duże firmy); natomiast hipoteza H1: wartość średnia (mniejsze firmy) ₹ wartości średniej (duże firmy). Kryterium grupowania ubezpieczycieli była składka przypisana brutto w 2019 r.; do dużych firm zaliczono następujące zakłady ubezpieczeń: Allianz Polska SA, Ergo Hestia SA, Generali SA, PZU SA, Warta SA; ${ }^{* * *}$ przy poziomie a=0,01.

Źródło: obliczenia własne.

Dane z tabeli 11. wskazują na wyższą efektywność kosztów dużych firm oraz wyższą efektywność zysków dla mniejszych firm. Test-u sugeruje nieistotne różnice między wartościami

34. K.E. Rogers, Non-traditional activities and the efficiency of US commercial banks, "Journal of Banking and Finance"1998, Vol. 22 No. 4, s. 477-482. 
przeciętnymi w efektywności kosztów i efektywności zysków przy poziomie istotności równym 1\%. Relatywnie wysoka efektywność kosztów dla dużych firm oznacza lepsze wykorzystanie ich skali działalności, co wpływa na obniżenie ich kosztów. Najprawdopodobniej świadczy to o tym, że fuzje i konsolidacje, zwiększając ich skalę działalności, przyczyniają się do zwiększania ich efektywności kosztów.

\section{Podsumowanie}

W pierwszej części artykułu zbadano strukturę i dynamikę rozwojową rynku ubezpieczeń non-life, uwzględniając w szczególności udział inwestycji zagranicznych, poziom koncentracji rynku, główne linie biznesowe oraz wyniki finansowe ubezpieczycieli.

Analiza zmian w rozwoju polskiego rynku ubezpieczeń non-life wykazała następujące jego cechy: znacząco niższe parametry rozwoju niż rynki zachodnioeuropejskie, wysoki udział inwestycji zagranicznych w kapitale spółek krajowych, wysoki poziom koncentracji, dominacja ubezpieczeń komunikacyjnych oraz stabilne wyniki finansowe.

W analizie efektywności firm wykorzystano standardowy model SFA translogarytmicznej funkcji kosztów oraz funkcji zysków. Badania oparto na danych z 18 zakładów ubezpieczeń (spółek komercyjnych] w dziale ubezpieczeń non-life w Polsce, w latach 2011-2019. Estymację modelu SFA przeprowadzono metodą największej wiarygodności, przy założeniu, że zmienna losowa modelująca nieefektywność $\left(u_{i t}\right)$ jest zmienną o rozkładzie wykładniczym.

Wyniki badań wykazały wysoki poziom efektywności zysków i niższy - efektywności kosztów. Przeciętny ubezpieczyciel osiagał blisko 84\% optymalnego zysku, a przeciętny ubezpieczyciel przekroczył o ponad 30,4\% estymowaną funkcję graniczną kosztów. Przeciętne wartości efektywności kosztów i efektywności zysków zmieniały się w czasie oraz wykazywały duże zróżnicowanie wśród firm. Grupa firm tzw. dużych (pięć największych zakładów ubezpieczeń) wykazała się wyższa przeciętną efektywnością kosztów od firm mniejszych, co może wskazywać na lepsze wykorzystanie przez nie skali działalności. Natomiast wyższą przeciętną efektywnością zysków charakteryzowała się grupa tzw. firm mniejszych. W badanym okresie wystapiła też wyższa relatywnie zmienność w efektywności kosztów niż w efektywności zysków oraz niska korelacja między wartościami tych efektywności - ta ostatnia, sugeruje że efektywność kosztów niekoniecznie sprzyja efektywności zysków.

\section{Wykaz źródeł}

Aigner D., Lovell C., \& Schmidt P., Formulation and estimation of stochastic frontier production function models, "Journal of Econometrics" 1977, No. 6.

Alhassan A.L., Biepke N., Competition and efficiency in the non-life insurance market in South Africa, "Journal of Economic Studies" 2016, Vol. 43, Issue 6.

Battese G.E., Coelli T.J., A model for technical inefficiency effects in a stochastic frontier production function for panel data, "Empirical Economics" 1995, No. 20.

Battese G.E., Coelli T.J., Frontier production functions, technical efficiency and panel data: With application to paddy farmers in India, "Journal of Productivity Analysis" 1992, No. 3. 
Berger A.N., Mester L.J., Inside the black box: What explains differences in the efficiencies of financial institutions, "Journal of Banking and Finance"1997, No. 21.

Biuletyn Roczny. Rynek ubezpieczeń, 2011-2019, ww.knf.gov.pl [dostęp: 11.12.2021].

Charnes A., Cooper W.W., Rhodes E., Measuring the Efficiency of Decision Making Units, "European Journal of Operational Research"1978, No. 2.

Choi B.P., Elyasiani E., Foreign-owned insurer performance in the US property-liability markets, "Applied Economics" 2011, Vol. 43, No. 3.

Cummins J.D., Xie X., Efficiency, productivity, and scale economies in The U.S. property-liability insurance industry, "Journal of Productivity Analysis" 2013, Vol. 39, No. 2.

Delis M.D., Koutsomanoli-Fillipaki A., Staikouras Ch. K., Evaluating cost and profit efficiency: A comparison of parametric and non-parametric methodologies, "MPRA Paper" 2009, No. 14039, https://mpra.ub.uni-muenchen.de/14039/ [dostęp: 6.08.2021].

Eling M., Luhnen M., Efficiency in the international insurance industry: a cross-country comparison, "Journal of Banking and Finance" 2010, Vol. 34, No. ?.

Fenn F., Vencappa D., Diacon S., Klumpes P., O'Brien C., Market structure and the efficiency of European insurance companies: a stochastic frontier analysis, "Journal of Banking and Finance" 2008, Vol. 32, No. 1.

Ferro G., Leon S., A Stochastic Frontier Analysis of Efficiency in Argentina's Non-Life Insurance Market, "Geneva Papers on Risk and Insurance - Issue and Practice" 2018, Vol. 43, Issue 1, No ?. Grmanová E., Pukała R., Efficiency of insurance companies in the Czech Republic and Poland, "Oeconomia Copernicana" 2018, No. 9[1].

Hao J.C.J., Chou L.-Y., The estimation of efficiency for life insurance industry: the case in Taiwan, "Journal of Asian Economics" 2005, Vol. 16, No. 5.

Hardwick P., Adams M., Zou H., Board characteristics and profit efficiency in the United Kingdom life insurance industry, "Journal of Business Finance and Accounting" 2011, Vol. 38 No. ?-8. Holló D., Nagy M., Bank Efficiency in the Enlarged European Union, Budapest, MNB Working Papers 2006/3, http://pdc.ceu.hu/archive/00004387/01/wp2006_3.pdf [dostęp: 6.08.2021].

Kasman A., Turgutlu E., Cost efficiency and scale economies in the Turkish insurance industry, "Applied Economics" 2009, Vol. 41, No. 24.

Kasman A., Turgutlu E., Performance of European insurance firms in the single insurance market, "International Review of Applied Economics" 2011, Vol. 25, Issue 3.

Kozak S., Efficiency of non-life insurance companies and its determinants, "Acta Scientarum Polonorum Oeconomia" 2018, Vol. 17 (4).

Kozak S., Forma prawna zakładu ubezpieczeń majatkowych a jego efektywność, „Studia Ekonomiczne. Zeszyty Naukowe Uniwersytetu Ekonomicznego w Katowicach” 2019, nr 387.

Marzec J., Pisulewski A., Pomiar efektywności zróżnicowanych technologicznie gospodarstw rolnych w Unii Europejskiej, „Gospodarka Narodowa” 2020, nr 3[303).

Marzec J., Pisulewski A., Prędki A., Efektywność techniczna i produktywność polskich gospodarstw rolnych specjalizujacych się w uprawach rolnych, „Gospodarka Narodowa” 2019, nr 2(298). Meeusen W., van den Broeck J., Efficiency estimation from Cobb-Douglas production functions with composed error, "International Economic Review" 197?, No. 18[2].

OECD data, https://stats.oecd.org/ [dostęp: 6.08.2021]. 
Ortyński K., Pypeć M., Competition in the Polish non-life insurance market, [w:] Competitiveness and Economic Development in Europe. Prospects and Challenges, Bukowski S.I., Hyz A., Lament M.B. [red.], Routledge Taylor \& Francis Group, London-New York 2021.

Polska Izba Ubezpieczeń (PIU], Raporty roczne, lata 2011-2019, https://piu.org.pl [dostęp: 6.08.2021].

Rogers K.E., Non-traditional activities and the efficiency of US commercial banks, "Journal of Banking \& Finance" 1998, Vol. 22, No. 4.

Wicaksono R., Mulyaningsih T., Does ownership structure matter? A cost efficiency study of life insurance firms in Indonesia, "Bulletin of Monetary Economics and Banking" 2019, Vol. 22, No. 3. Wskaźniki cen towarów i usług konsumpcyjnych, https://stat.gov.pl/ [dostęp: 6.08.2021].

\section{Technical efficiency of non-life insurance companies}

The insurance market is an important part of a financial system, and insurance business is an important element in risk management and revenue volatility management.

The purpose of this study was to examine the cost efficiency and profit efficiency of insurers and their mutual correlation with the application of stochastic frontier analysis (SFA). The study used descriptive statistics methods and the SFA model.

SFA models belong to parametric stochastic frontier models for estimating inefficiency. Efficiencies of the studied insurers were estimated on the basis of the determined inefficiency values. The analysis is based on the annual financial data (2011-2019] of 18 Polish non-life insurance companies (joint stock companies].

The study showed that the average cost efficiency was 0.6958 and the average profit efficiency was 0.8382 . In the period considered, there was a relatively higher variability in the cost efficiency than in the profit efficiency and a low correlation between the values of these efficiencies. The structure and development of the non-life insurance sector in Poland was also assessed, taking into account selected $\varepsilon U$ countries.

Keywords: non-life insurance market, cost efficiency, profit efficiency, stochastic frontier analysis.

PROF. DR HAB. KAZIMIERZ ORTYŃSKI - Wydział Ekonomii i Finansów, Kierownik Katedry Finansów i Ubezpieczeń, Uniwersytet Technologiczno-Humanistyczny im. Kazimierza Pułaskiego w Radomiu e-mail: k.ortynski@uthrad.pl

ORCID: 0000-0002-8078-230x

DR INŻ. JACEK WOŁOSZYN - Wydział Transportu, Elektrotechniki i Informatyki, p.o. Kierownika Katedry Informatyki, Uniwersytet Technologiczno-Humanistyczny im. Kazimierza Pułaskiego w Radomiu e-mail: jacek.woloszyn@uthrad.pl

ORCID: 0000-0003-4340-9853 
